\title{
An interesting case of familial chylomicronemia syndrome in a cleft palate child
}

\author{
H. S. Adenwalla, P. V. Narayanan, C. J. Rajshree, Rati Santhakumar ${ }^{1}$ \\ Departments of Plastic Surgery, ${ }^{1}$ Pediatrics and Burns, Charles Pinto Centre for Cleft Lip, Palate and Craniofacial Anomalies, \\ Jubilee Mission Medical College and Research Institute, Trichur - 680 005, Kerala, India
}

Address for correspondence: Dr. HS Adenwalla, Department of Plastic Surgery, Burns, Charles Pinto Centre for Cleft Lip, Palate and Craniofacial Anomalies, Jubilee Mission Medical College and Research Institute, Trichur - 680 005, Kerala, South India.

E-mail: charlespinto@sify.com

\section{ABSTRACT}

Familial chylomicronemia syndrome is a very rare condition with an incidence of one in one million. We report such a condition detected incidentally in a cleft child.

\section{KEY WORDS}

Familial hyperlipoprotenemia, lipoprotein lipase

\section{INTRODUCTION}

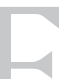

amilial chylomicronemia usually manifests in $\checkmark$ childhood at around ten years of age with recurrent abdominal pain and pancreatitis. This disorder is usually clinically silent and hence not discovered till blood is sampled for some other reason. During sampling, massive elevation of triglycerides $(1,000 \mathrm{mg} /$ $\mathrm{dl}->10,000 \mathrm{mg} / \mathrm{dl}$ ) is noted. In our asymptomatic case, the diagnosis was made during surgery.

\section{CASE HISTORY}

A fifteen month-old male child who had undergone cleft lip repair at five months of age and in whom nothing abnormal was found at that stage, was later taken up for cleft palate repair. Peroperatively at the incision sites, the blood was found to be milky [Figure 1]. Blood drawn by venepuncture. was also of a similar nature. This was then sent for biochemical analysis [Figure 2]. The results are shown in Table 1.

Further investigations done gave the following results:
1. Serum albumin
$4 \mathrm{gms} / \mathrm{dl}$

2. High density $23 \mathrm{mg} / \mathrm{dl}$ lipoprotein (HDL)

3. Urine sugar Nil

4. Urine protein Nil

5. Triiodothyronine (T3) $1.02 \mathrm{ng} / \mathrm{dl}$

6. Thyroxine (T4) $\quad 9.6 \mu \mathrm{g} / \mathrm{dl}$

7. Thyroid-stimulating $\quad 0.80 \mu \mathrm{IU} / \mathrm{ml}$ hormone (TSH)

8. Blood urea $\quad 50 \mathrm{mg} / \mathrm{ml} \quad 1^{\text {st }}$ sample $19 \mathrm{mg} / \mathrm{ml} \quad 2^{\text {nd }}$ sample 2 days later

9. Serum creatine $\quad 1 \mathrm{mg} / \mathrm{dl} \quad 1^{\text {st }}$ sample $0.3 \mathrm{mg} / \mathrm{dl} \quad 2^{\text {nd }}$ sample 2 days later

10. Growth factor receptor-bound blood $\quad 84 \mathrm{mg} / \mathrm{dl}$ sugar (GRBS)

A diagnosis of familial chylomicronemia was made. Postoperatively the child was put on a low-fat diet and advised medium chain triglycerides in the form of coconut oil. The palate has healed well and the child has been discharged home uneventfully. 


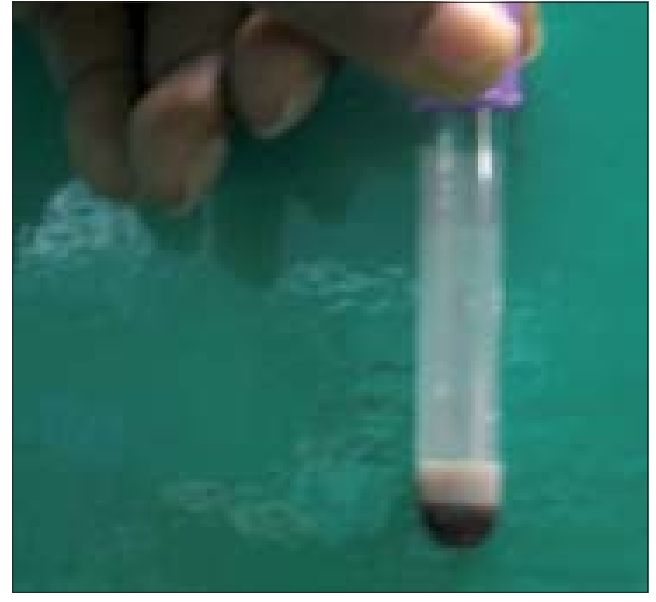

Figure 1: Appearance of centrifuged blood - plasma appears lipid laden

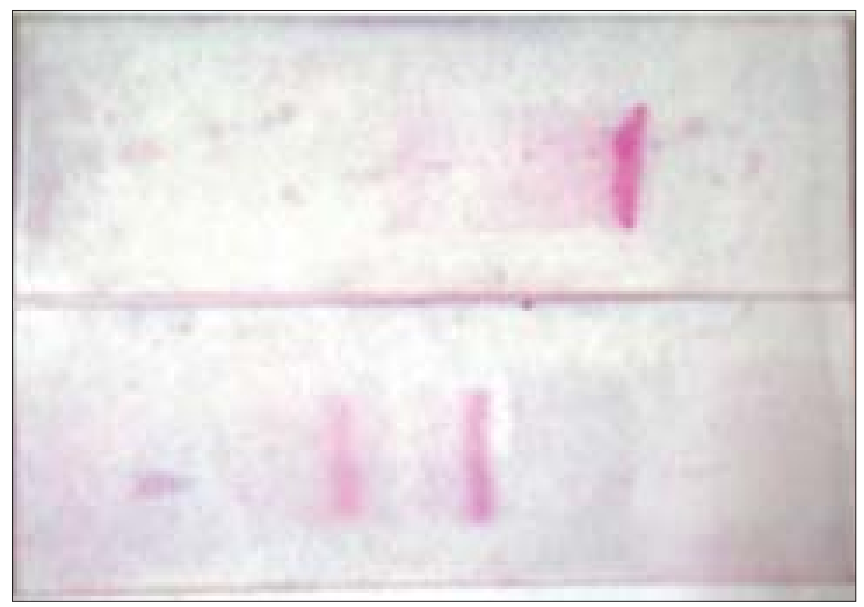

Figure 2: Picture of blood electrophoresis: Chylomicrons appear dominant

\section{DISCUSSION}

Of the various Familial Dyslipoprotenemias, Type I Hyperlipoprotenemia or Familial Chylomicronemia is very rare and is autosomal recessive. ${ }^{[1]}$ It is characterized by marked hyperchylomicronemia and a corresponding hypertriglyceridemia (triglyceride as high as $10,000 \mathrm{mg} /$ $\mathrm{dL}$ ). It may be due to the deficiency of Lipoprotein Lipase (LPL) activity or deficiency of Apolipoprotein C-II. Lipoprotein Lipase is essential for the hydrolysis of triglycerides and the conversion of chylomicrons to chylomicron remnants. The massive accumulation of chylomicrons in the circulation indicates the inability to catabolize dietary fat. The concentration of very low density lipoprotein (VLDL) cholesterol is usually normal.

This disorder is usually expressed in childhood. It appears that those patients with low to absent LPL activity in all tissues present with the disease at an early age (classic form) whereas those with a deficiency of LPL activity in only one tissue become symptomatic later in life (variant form). This disease is usually detected after recurrent episodes of severe abdominal pain and repeated attacks of pancreatitis. ${ }^{[2]}$ The possible mechanism of pancreatitis is the lipolysis of triglycerides that produces high concentrations of free fatty acids in the vicinity of the pancreas which damage small vessels and produce ischemic injury; they may also be toxic to the cell membranes of the acinar cells.

Eruptive xanthomas and lipemia retinalis are usually present when the plasma triglyceride concentrations exceed 2000 and $4000 \mathrm{mg} / \mathrm{dL}$ respectively. ${ }^{[3]}$ Xanthomas are painless skin lesions on the back, buttocks and extensor surfaces of the arms and legs. The acuteness of the symptoms is directly proportional to the degree of hyperchylomicronemia. It is important to note that patients with this disorder do not appear to be predisposed to atherosclerotic disease.

Chylomicronemiacanalsocauseneurologicalmanifestations and dyspnea. ${ }^{[4]}$ Accumulation of triglycerides in reticuloendothelial cells can cause hepatosplenomegaly.

LPL deficiency is suspected in any person who has a lipemic serum after a 12 hour fast. Fasting plasma is turbid and if left at $4^{\circ} \mathrm{C}$ for a few hours, the chylomicrons float to the top and form a creamy supernatant.

Many secondary causes of this condition have been reported $^{[5]}$ and are listed in Table 2.

The diagnosis of chylomicronemia is made by the determination of LPL activity in plasma after an intravenous administration of heparin. Heparin binds with LPL causing

Table 1: Plasma cholesterol and triglyceride mean level and percentile levels

\begin{tabular}{|c|c|c|c|c|c|c|c|c|c|c|}
\hline \multirow[b]{2}{*}{$1-4$ years } & \multicolumn{5}{|c|}{ Total triglyceride level (mg/dl) } & \multicolumn{5}{|c|}{ Total cholesterol level (mg/dl) } \\
\hline & $5^{\text {th }}$ & Mean & $75^{\text {th }}$ & $90^{\text {th }}$ & $95^{\text {th }}$ & $5^{\text {th }}$ & Mean & $75^{\text {th }}$ & $90^{\text {th }}$ & $95^{\text {th }}$ \\
\hline Normal male & 29 & 56 & 68 & 85 & 99 & 114 & 155 & 170 & 190 & 203 \\
\hline Normal female & 34 & 64 & 74 & 95 & 112 & 112 & 156 & 173 & 188 & 200 \\
\hline This child & \multicolumn{5}{|c|}{ Triglyceride 7000 mg/dl } & \multicolumn{5}{|c|}{ Cholesterol 495 mg/dl } \\
\hline
\end{tabular}


Table 2: Secondary causes of chylomicronemia

Nephrotic syndrome

Hypothyroidism

Renal failure

Storage disease

Systemic lupus erythematosus

Diabetes mellitus

Congenital biliary atresia

Excessive alcohol intake

Drugs-oral contraceptive pills, thiazide diuretics

its dissociation from heparan sulfate present on the surface of endothelial cells with its subsequent release into plasma.

Patients with a deficiency of Apolipoprotein C-II, the required activator for LPL have similar clinical symptoms but they are usually milder and expressed at a later age. Those affected have less than $10 \%$ of the normal concentration of Apo C-II, the minimum amount needed for normal LPL activity. Diagnosis is by the documentation of low LPL activity in postheparin plasma and the restoration of normal enzymatic activity by addition of normal Apo C-II to the assay mixture. Another diagnostic method is by immunoassay for Apo C-II.
As far as long term management is concerned, these patients are placed on a very low fat diet (10-15 g/day in a child). As medium chain triglycerides are absorbed directly from the portal vein, they are used to replace some of the dietary long chain fats for these patients. In cases where fasting triglyceride concentration is over $1000 \mathrm{mg} / \mathrm{dL}$ and the patient is already on a fat restricted diet, drug therapy is recommended to reduce the risk of development of pancreatitis.

\section{REFERENCES}

1. Rifai N, Warnick RG. Lipids, lipoproteins, apolipoproteins and other cardiovascular risk factors. TIETZ Textbook of Clinical Chemistry and Molecular Diagnostics: 2006. p. 929,935,938.

2. Henderson RA, Rinker AD. Gastric, pancreatic and intestinal function. TIETZ Text book of Clinical Chemistry: 1998. p. 1310.

3. Mahley RW, Weisgreber KH, Farese RV Jr. Disorders of lipid metabolism. 10 $0^{\text {th }}$ ed. Williams Textbook of Endocrinology: 1675.

4. Rader DJ, Hobbs HH. Disorders of lipid metabolism. Harrisons Principles of Internal Medicine. $16^{\text {th }}$ ed. 2289.

5. Tershakove AM, Rader DJ. Defects in metabolism and lipids; 75.3 - Disorders of Lipoprotein metabolism and Transport. Nelsons Textbook of Pediatrics, $17^{\text {th }}$ ed. p. 448.

Source of Support: Nil, Conflict of Interest: None declared.

\section{Author Help: Reference checking facility}

The manuscript system (www.journalonweb.com) allows the authors to check and verify the accuracy and style of references. The tool checks the references with PubM ed as per a predefined style. Authors are encouraged to use this facility before submitting articles to the journal.

- The style as well as bibliographic elements should be $100 \%$ accurate to get the references verified from the system. A single spelling error or addition of issue number / month of publication will lead to error to verifying the reference.

- Example of a correct style

Sheahan P, O'leary G, Lee G, Fitzgibbon J . Cystic cervical metastases: Incidence and diagnosis using fine needle aspiration biopsy. Otolaryngol Head Neck Surg 2002;127:294-8.

- Only the references from journals indexed in PubM ed would be checked.

- Enter each reference in new line, without a serial number.

- Add up to a maximum 15 reference at time.

- If the reference is correct for its bibliographic elements and punctuations, it will be shown as CORRECT and a link to the correct article in PubM ed will be given.

- If any of the bibliographic elements are missing, incorrect or extra (such as issue number), it will be shown as INCORRECT and link to possible articles in PubM ed will be given. 